Authors' contribution/

Wkład autorów:

A. Zaplanowanie badań/

Study design

B. Zebranie danych/

Data collection

C. Analiza statystyczna/

Statistical analysis

D. Interpretacja danych/

Data interpretation

E. Przygotowanie tekstu/

Manuscript preparation

F. Opracowanie

piśmiennictwa/

Literature search

G. Pozyskanie funduszy/

Funds collection

ISSN 2083-3725

Volume 10, No. 2, 2017

\title{
EXPLOITATION AND PROTECTION OF RESOURCES IN ECOLOGICAL FARMS OF A SUBREGION OF LUBLIN VOIVODESHIP
}

\author{
WYKORZYSTANIE I OCHRONA ZASOBÓW W GOSPODARSTWACH \\ EKOLOGICZNYCH PODREGIONU WOJEWÓDZTWA LUBELSKIEGO
}

\author{
Agnieszka Siedlecka
}

Pope John Paul II State School of Higher Education in Biała Podlaska

Państwowa Szkoła Wyższa im. Papieża Jana Pawła II w Białej Podlaskiej

Siedlecka A. (2017), Exploitation and protection of resources in ecological farms of a subregion of Lublin Voivodeship/ Wykorzystanie i ochrona zasobów w gospodarstwach ekologicznych podregionu województwa lubelskiego. Economic and Regional Studies, Vol. 10, No. 2, pp. 5-15. https://doi.org/10.2478/ers-2017-0011

\section{ORIGINAL ARTICLE}

JEL code: D19, Q57, Q10

Submitted:

November 2014

Accepted:

April 2017

Tables: 4

Figures: 2

References: 14

\section{Summary}

Subject and purpose of work: The purpose of the study is to evaluate the utilisation of resources necessary for agricultural production as well as their protection in farms conducting ecological production. The deliberations undertaken in this paper focus on certified farms due to their specificity and character of their production, which is compatible with the principles of sustainable development. Materials and methods: The article uses the results of research from twenty ecological farms in the ChełmZamość subregion of Lublin Voivodeship. The deciding factor in selecting this region was the prominent role of agricultural production in this region when compared to the other ones in the voivodeship.

Results: The research results have shown that there is a lack of correlation between actions taken by producers and caring for the natural environment. Farmers displayed little awareness with regard to the use of environmental resources and assets in agricultural production.

Conclusions: Running a farm aimed at ecological production is connected with the implementation of solutions that have not found application in traditional agricultural production, with obtaining a certificate and the need for training and further study. This does not, however, translate into the introduction of pro-ecological solutions in agricultural production or the farm itself. A significant share of the investigated producers did not report the need for introducing such solutions. It indicates the need for continuous broadening of knowledge and creating ecological.

Keywords: farm, farms, ecological farming, bioeconomics

\section{Streszczenie}

ORYGINALNY ARTYKUŁ NAUKOWY

Klasyfikacja JEL: D19, Q57, Q10

Zgłoszony:

Listopad 2014

Zaakceptowany:

Kwiecień 2017

Tabele: 4

Rysunki: 2

Literatura: 14
Przedmiot i cel pracy: Celem opracowania jest ocena wykorzystania zasobów niezbędnych w produkcji rolniczej i ich ochrony w gospodarstwach prowadzących produkcję ekologiczną. Rozważania podjęte $\mathrm{w}$ artykule koncentrują się na certyfikowanych gospodarstwach rolnych z uwagi na ich specyfikę i charakter realizowanej produkcji, która sama w sobie jest zgodna z zasadami rozwoju zrównoważonego. Materiały i metody: W artykule wykorzystano wyniki badań dwudziestu gospodarstw ekologicznych z terenu podregionu chełmsko-zamojskiego województwa lubelskiego. 0 wyborze podregionu zdecydowała znacząca rola produkcji rolniczej w regionie na tle pozostałych w województwie.

Wyniki: Uzyskane wyniki badań wskazały na brak powiązania podejmowanych przez producentów działań z dbałością o środowisko przyrodnicze. Rolnicy charakteryzowali się niewielką świadomością dotyczącą wykorzystywania zasobów i walorów środowiskowych w produkcji rolniczej.

Wnioski: Prowadzenie gospodarstwa ukierunkowanego na produkcję ekologiczną jest związane $\mathrm{z}$ wprowadzaniem rozwiązań nie stosowanych w tradycyjnej produkcji rolniczej, uzyskaniem certyfikatu, a także potrzebą szkolenia i dokształcanie. Nie przekłada się to jednak na wprowadzanie rozwiązań proekologicznych w produkcji rolniczej i w samym gospodarstwie domowym. Znacząca część badanych producentów nie wykazała potrzeby wprowadzania takich rozwiązań. Wskazuje to na potrzebę ciągłego poszerzania wiedzy i kreowania świadomości ekologicznej.

Address for correspondence/ Adres korespondencyjny: dr Agnieszka Siedlecka, Państwowa Szkoła Wyższa im. Papieża Jana Pawła II w Białej Podlaskiej Wydział Nauk Ekonomicznych i Technicznych, ul. Sidorska 95/97, 21-500 Biała Podlaska, Polska; tel. +48 83344 99 05; e-mail: a.siedlecka@wp.pl

Journal indexed in/ Czasopismo indeksowane w: AgEcon Search, AGRO, BazEkon, Index Copernicus Journal Master List, ICV 2015: 81,26; Polish Ministry of Science and Higher Education 2016: 9 points/ AgEcon Search, AGRO, BazEkon, Index Copernicus Journal Master List ICV 2015: 81,26; Ministerstwie Nauki i Szkolnictwa Wyższego 2016: 9 punktów. Copyright: (c) 2017 Pope John Paul II State School of Higher Education in Biała Podlaska, Agnieszka Siedlecka. All articles are distributed under the terms of the Creative Commons Attribution-NonCommercial-ShareAlike 4.0 International (CC BY-NC-SA 4.0) License (http://creativecommons.org/licenses/by-nc-sa/4.0/), allowing third parties to copy and redistribute the material in any medium or format and to remix, transform, and build upon the material, provided the original work is properly cited and states its license. 


\section{Introduction}

Environmental resources and their usage are a top priority both in theoretical and practical economics. Bioeconomics is the field of science which pays special attention to this problem. When attempting to designate areas of bioeconomy, one should refer to various approaches and definitions of the term. One definition of bioeconomy indicates that it is a part of economy which generates growth and jobs through the development, processing and utilisation of biological resources in a sustainable way (Quinn 2010).

The development of bioeconomy is possible thanks to the use of environmental resources. Since these resources are limited, utilising them in a reasonable and sustainable way is necessary. For this reason, a very important issue, with respect to the development of bioeconomy, is to refer to the concept of sustainable development, as pointed out in the strategy "Innovations in the service of sustainable growth: bioeconomy for Europe". This document defines the goals of the strategy concerning bioeconomy and planned measures, assumes "the creation of foundations for a more innovative, resource-efficient and competitive society, in which ensuring food security does not conflict with the rules of sustainable use of renewable resources for industrial purposes, while ensuring environmental protection" (Commission Announcement 2012, p. 2).

The issue of bioeconomy can be analysed from two perspectives: resource-based and process-based. The resource-based approach refers to production based on natural resource, while the process-based approach takes into account the use of biotechnology (Ratajczak 2013).

Bioeconomy is interdisciplinary by nature. It is composed of, among others, agriculture, forestry, fishing, food, paper and pulp production, as well as some sectors of the chemical, biotechnological and energy industry. (Commission Announcement 2012).

The concept of sustainable development was born due to the recognition of the phenomenon of natural environment degradation. Environmental pollution problems, and thus problems concerning the quality of food and other elements essential for human life, have brought the attention of governments and societies to the issues of quality of life and sustainable development (Gołębiewski 2013).

The concept of sustainable development can be defined as "Socioeconomic development, in which the process of integrating political, economic and social activities takes place, preserving the natural balance and the permanence of basic natural processes, in order to guarantee the ability to meet the basic needs of respective communities or citizens of current and future generations" (Natural Environment Protection Act). A number of other definitions can also be found in the literature dealing with this subject. However, most of them focus on the issues of "meeting the needs of the current generation without compromising the ability of future ones to meet

\section{Wstęp}

Zasoby środowiska i ich wykorzystanie jest priorytetowym zagadnieniem zarówno w teorii, jak i praktyce ekonomii. Dziedziną nauki, która zwraca szczególną uwagę na tę problematykę jest biogospodarka. Podejmując próbę wyznaczania obszarów biogospodarki należy odnieść się do różnych podejść i definicji terminu. Jedna z definicji biogospodarki wskazuje, iż jest to część ekonomii, która generuje wzrost i miejsca pracy dzięki rozwojowi, przetwarzaniu i wykorzystywaniu zasobów biologicznych w sposób zrównoważony (Quinn 2010).

Rozwój biogospodarki możliwy jest dzięki wykorzystaniu zasobów środowiskowych. Z uwagi na to, iż zasoby te są ograniczone, konieczne jest ich rozsądne i zrównoważone wykorzystanie. $\mathrm{Z}$ tego powodu niezwykle ważnym zagadnieniem $\mathrm{z}$ punktu widzenia rozwoju biogospodarki jest odniesienie się do koncepcji rozwoju zrównoważonego, na co zwrócono uwagę w Strategii „Innowacje w służbie zrównoważonego wzrostu: biogospodarka dla Europy". Dokument ten definiuje cele strategii w odniesieniu do biogospodarki i planowanych działań, zakłada „stworzenie podstaw dla bardziej innowacyjnego, zasobooszczędnego i konkurencyjnego społeczeństwa, w którym zapewnienie bezpieczeństwa żywnościowego nie wchodzi w konflikt z zasadami zrównoważonego wykorzystania zasobów odnawialnych dla celów przemysłowych, przy jednoczesnym zapewnieniu ochrony środowiska" (Komunikat Komisji 2012, s. 2).

Zagadnienie biogospodarki można analizować z dwóch punktów widzenia: zasobowego i procesowego. Ujęcie zasobowe odnosi się do produkcji opierającej się na zasobach przyrodniczych, natomiast ujęcie procesowe uwzględnia wykorzystanie biotechnologii (Ratajczak 2013).

Biogospodarka ma charakter interdyscyplinarny. W jej skład wchodzą między innymi rolnictwo, leśnictwo, rybołówstwo, żywność, produkcja papieru i pulpy, a także niektóre sektory przemysłu chemicznego, biotechnologicznego i energetycznego (Komunikat Komisji 2012).

Koncepcja rozwoju zrównoważonego zrodziła się w związku z dostrzeżeniem zjawiska degradacji środowiska naturalnego. Problemy z zanieczyszczeniem środowiska, a przez to z jakością żywności oraz innych elementów niezbędnych do życia człowieka zwróciły uwagę nie tylko rządów, ale również społeczeństw na zagadnienia związane z jakością życia i rozwojem zrównoważonym (Gołębiewski 2013).

Pojęcie rozwoju zrównoważonego można zdefiniować jako „rozwój społeczno-gospodarczy, w którym następuje proces integrowania działań politycznych, gospodarczych i społecznych, z zachowaniem równowagi przyrodniczej oraz trwałości podstawowych procesów przyrodniczych, w celu zagwarantowania możliwości zaspokajania podstawowych potrzeb poszczególnych społeczności lub obywateli zarówno współczesnego pokolenia, jak i przyszłych pokoleń" (Ustawa Prawo ochrony środowiska). W literaturze przedmiotu znaleźć można również szereg innych definicji. Jednakże w większości z nich szczególną uwa- 
their own needs" (Report of the World Commission 1987).

One of the economic sectors playing a significant role in the creation of bioeconomy is the agri-food sector. The increasing population and consumption of highly processed products contribute to upward trends in this sector. Currently, the food sector provides $18 \%$ of marketed production in Poland and this figure might increase in the future (Food Sector in Poland). It should be noted that the changing purchasing attitudes of consumers, linked primarily to income growth and the need for healthy eating, result in the increased importance attached to ecological production of quality food.

The beginning of ecological farming development in Poland dates back to the 80s and 90s of the twentieth century. Poland's accession to the European Union was a period of increased interest in this type of agricultural production. This was in part due to the commencement of the implementation of environmental management schemes, constituting a subsidising system for farmers applying eco-friendly farming techniques (Siedlecka 2013).

Lublin Voivodeship is a typically agricultural area with a fragmented land ownership and agricultural production structure. The variables testifying to this fact include a large area of farmland, and the share of agricultural land in the total area, which the highest in Poland. The restructuring of farms in Lublin voivodeship is manifested primarily in the development of ecological production and the creation of new jobs associated with it. In 2013, there were 2180 ecological producers in the region, constituting $12 \%$ of such producers in Poland, and 45 ecological processing plants. A greater number of processing plants was located only in the Mazowieckie Voivodeship (78) and Wielkopolskie Voivodeship (53). Ecological farming is a rapidly developing manner of agricultural production. Lublin Voivodeship is characterized by a high potential for agricultural production. In recent years, the creation of larger and more efficient farms has been observed, which will help improve their economic situation (Diagnosis of the situation...). gę zwraca się na problematykę „zaspokajania potrzeb obecnego pokolenia bez narażania zdolności przyszłych do zaspokajania własnych potrzeb" (Report of the World Commission 1987).

Jednym z sektorów gospodarki o znaczącej roli w kreowaniu biogospodarki, jest sektor rolno-spożywczy. Zwiększająca się liczba ludności oraz konsumpcja produktów wysoko przetworzonych wpływają na tendencje wzrostowe $\mathrm{w}$ tym sektorze. W chwili obecnej sektor spożywczy dostarcza 18\% produkcji sprzedanej przemysłu w Polsce, a w przyszłości wielkość ta może się zwiększyć (Sektor spożywczy w Polsce). Należy zaznaczyć, iż zmieniające się postawy nabywcze konsumentów, związane między innymi ze wzrostem dochodów oraz potrzebą zdrowego odżywiania powodują, iż wzrasta rola produkcji ekologicznej dostarczającej żywność wysokiej jakości.

Początki rozwoju rolnictwa ekologicznego w Polsce sięgają lat 80. i 90. XX wieku. Wejście Polski do Unii Europejskiej stanowiło okres wzmożonego zainteresowania tego rodzaju produkcją rolną. Było to między innymi wynikiem rozpoczęcia realizacji programów rolno-środowiskowych, stanowiących system dotacji dla rolników stosujących przyjazne dla środowiska metody gospodarowania (Siedlecka 2013).

Województwo lubelskie jest obszarem o charakterze typowo rolniczym o rozdrobnionej strukturze agrarnej. Zmiennymi wskazującymi na ten fakt jest duża powierzchnia użytków rolnych, a także najwyższy w Polsce udział użytków rolnych w powierzchni ogólnej. Restrukturyzacja gospodarstw na terenie Lubelskiego przejawia się m.in. w rozwoju produkcji ekologicznej i powiązanym z nim tworzeniu nowych miejsc pracy. W 2013 roku w regionie było 2180 producentów ekologicznych, co stanowiło $12 \%$ producentów w Polsce i 45 przetwórni ekologicznych. Większa liczba przetwórni była tylko w woj. mazowieckim 78 oraz wielkopolskim 53. Rolnictwo ekologiczne jest sposobem produkcji rolniczej, który rozwija się szybko. Województwo lubelskie charakteryzuje się dużym potencjałem produkcji rolniczej $\mathrm{w}$ ostatnich latach obserwuje się tworzenie większych i wydajniejszych gospodarstw, co pozwoli na poprawę ich sytuacji ekonomicznej (Diagnoza sytuacji...).

Table 1. Structure of gross value added as per types of activity (current prices) in 2011 for Lublin Voivodeship and subregions

Tabela 1. Struktura wartości dodanej brutto według rodzajów działalności (ceny bieżące) w roku 2011 dla podregionów i województwa lubelskiego

\begin{tabular}{|c|c|c|c|c|c|c|c|}
\hline & $\begin{array}{c}\text { total/ } \\
\text { ogółem }\end{array}$ & $\begin{array}{c}\text { agriculture/ } \\
\text { rolnictwo }\end{array}$ & $\begin{array}{c}\text { industry/ } \\
\text { przemysł }\end{array}$ & $\begin{array}{c}\text { architecture/ } \\
\text { budownictwo }\end{array}$ & $\begin{array}{c}\text { fomancial } \\
\text { handel } \\
\text { activity/ } \\
\text { działalność } \\
\text { finansowa }\end{array}$ & $\begin{array}{c}\text { others/ } \\
\text { pozostałe }\end{array}$ \\
\hline $\begin{array}{c}\text { voivodeship/ } \\
\text { województwo }\end{array}$ & 100.00 & 8.69 & 19.71 & 7.60 & 28.37 & 8.86 & 26.76 \\
\hline Biała Podlaska & 12.54 & 1.91 & 1.72 & 0.85 & 3.91 & 0.89 & 3.27 \\
\hline Chełm-Zamość & 24.77 & 3.28 & 4.51 & 1.54 & 6.74 & 1.99 & 6.72 \\
\hline Lublin & 42.19 & 1.62 & 8.10 & 3.57 & 12.45 & 4.55 & 11.89 \\
\hline Puławy & 20.49 & 1.88 & 5.39 & 1.65 & 5.28 & 1.43 & 4.87 \\
\hline
\end{tabular}

Source: own elaboration based on Lublin Voivodeship. Subregions, counties, communes, Lublin Statistical Office, Lublin 2013, p. 363.

Źródło: opracowanie własne na podstawie Województwo lubelskie. Podregiony, powiaty, gminy, Urząd Statystyczny w Lublinie, Lublin 2013, s. 363. 
Within Lublin Voivodeship we distinguish 20 counties, 4 towns with county status (Lublin, Chełm, Zamość, Biała Podlaska) and 213 communes (of which 20 are urban communes, 21 - urban-rural ones and 172 - rural ones). 4 subregions were distinguished as well: Lublin, Chełm-Zamość, Biała Podlaska and Puławy.

Through the analysis of gross value per type of activity (current prices) in 2011, it can be concluded that in comparison to other regions Chełm-Zamość subregion specialises in agriculture. In the case of Lublin subregion, a relatively high share of added value comes from industrial, commercial and repair services sectors along with attached sections (Table 1). Chełm-Zamość subregion seems to be predestined for the development of ecological production, which may strengthen the competitiveness of Lublin Voivodeship.

\section{Material and methods}

The purpose of the study is to evaluate the utilisation of resources necessary in agricultural production and their protection in farms conducting ecological production. The research was carried out in Chełm-Zamość subregion, which is characterized by a high share of agriculture in its economic structure. Research on a small number of subjects $(20$ ecological farms) was conducted between November 2013 and June 2014, within the research project No 2011/01/D/HS4/03927, entitled "Environmental preconditions and factors in the development of economic functions in high nature value areas of Lublin Voivodeship", funded by the National Science Centre. The research covered farms conducting certified ecological production and having over 5 hectares of area. The diagnostic survey method with questionnaire application was used to carry out the research. The questionnaire consisted of questions related to the characteristics of the conducted production activities as well as the issues related to the utilisation of resources in agricultural production.

\section{Results}

Farms conducting ecological production in Chełm-Zamość subregion of Lublin Voivodeship are characterized by an average area of 34.73 ha (standard deviation 22.14). They were farms aiming at further implementation of agricultural production. None of the farm managers envisaged discontinuation of production within the next five years. Only $5 \%$ of respondents declared undertaking a non-agricultural activity - Figure 1. The same group of respondents expressed their determination to change the profile of agricultural production. On the other hand, such trends of change in farm management were considered respectively by $16.7 \%$ and $21.1 \%$ of producers. In their plans for the coming years, farmers more often considered enlarging their farm area $-26.3 \%$.
W ramach województwa lubelskiego wyodrębniono 20 powiatów, 4 miasta na prawach powiatu (Lublin, Chełm, Zamość, Biała Podlaska) oraz 213 gmin (z czego 20 to gminy miejskie, 21 - miejsko-wiejskie i 172 - wiejskie). Wyróżniono także 4 podregiony: lubelski, chełmsko-zamojski, bialski oraz puławski.

Analizując wartość dodaną brutto według rodzajów działalności (ceny bieżące) w roku 2011 można wysnuć wniosek, iż podregion chełmsko-zamojski wyspecjalizowany jest na tle pozostałych regionów $\mathrm{w}$ rolnictwie. $\mathrm{W}$ przypadku podregionu lubelskiego relatywnie wysoki udział wartości dodanej pochodzi z sektora przemysłowego, handlu i napraw wraz z dołączonymi sekcjami (tabela 1). Wydaje się, iż podregion chełmsko-zamojski jest predystynowany do rozwoju produkcji ekologicznej, która może wzmocnić konkurencyjność województwa lubelskiego.

\section{Materiał i metody}

Celem opracowania jest ocena wykorzystania zasobów niezbędnych w produkcji rolniczej i ich ochrony $\mathrm{w}$ gospodarstwach prowadzących produkcję ekologiczną. Badania przeprowadzono w podregionie chełmsko-zamojskim który charakteryzuje się wysokim udziałem rolnictwa w strukturze gospodarczej. Badania na małej próbie podmiotów (20 gospodarstw ekologicznych) realizowano w okresie listopad 2013 - czerwiec 2014,w ramach projektu badawczego nr 2011/01/D/HS4/ 03927 pt. „Ekologiczne uwarunkowania i czynniki rozwoju funkcji gospodarczych na obszarach przyrodniczo cennych województwa lubelskiego", finansowanego ze środków Narodowego Centrum Nauki. Badaniami zostały objęte gospodarstwa prowadzące produkcję ekologiczną certyfikowaną o powierzchni powyżej 5 ha. Badania przeprowadzono metodą sondażu diagnostycznego z wykorzystaniem kwestionariusza ankiety. Kwestionariusz składał się z pytań odnoszących się zarówno do charakterystyki prowadzonej działalności produkcyjnej, jak także i kwestii związanych z wykorzystywaniem zasobów $\mathrm{w}$ produkcji rolniczej.

\section{Wyniki}

Gospodarstwa rolne prowadzące produkcję ekologiczną z terenu podregionu chełmsko-zamojskiego województwa lubelskiego to podmioty charakteryzujące się średnią powierzchnią 34,73 ha (odchylenie standardowe 22,14). Były to gospodarstwa ukierunkowane na dalsza realizacje produkcji rolniczej. Żaden z kierowników gospodarstw rolnych nie zakładał $\mathrm{w}$ okresie najbliższych 5 lat zaprzestania produkcji. Jedynie 5\% respondentów deklarowało podjęcie działalności pozarolniczej - wykres 1 . Taka sama grupa badanych wskazała, iż zdecydowana jest na zmianę profilu produkcji rolniczej. Rozważało natomiast takie kierunki zmian w gospodarstwie odpowiednio 16,7\% i 21,1\% producentów. Zdecydowanie częściej w swoich planach na nadchodzące lata rolnicy uwzględniali powiększenie obszaru gospodarstwa $-26,3 \%$. 


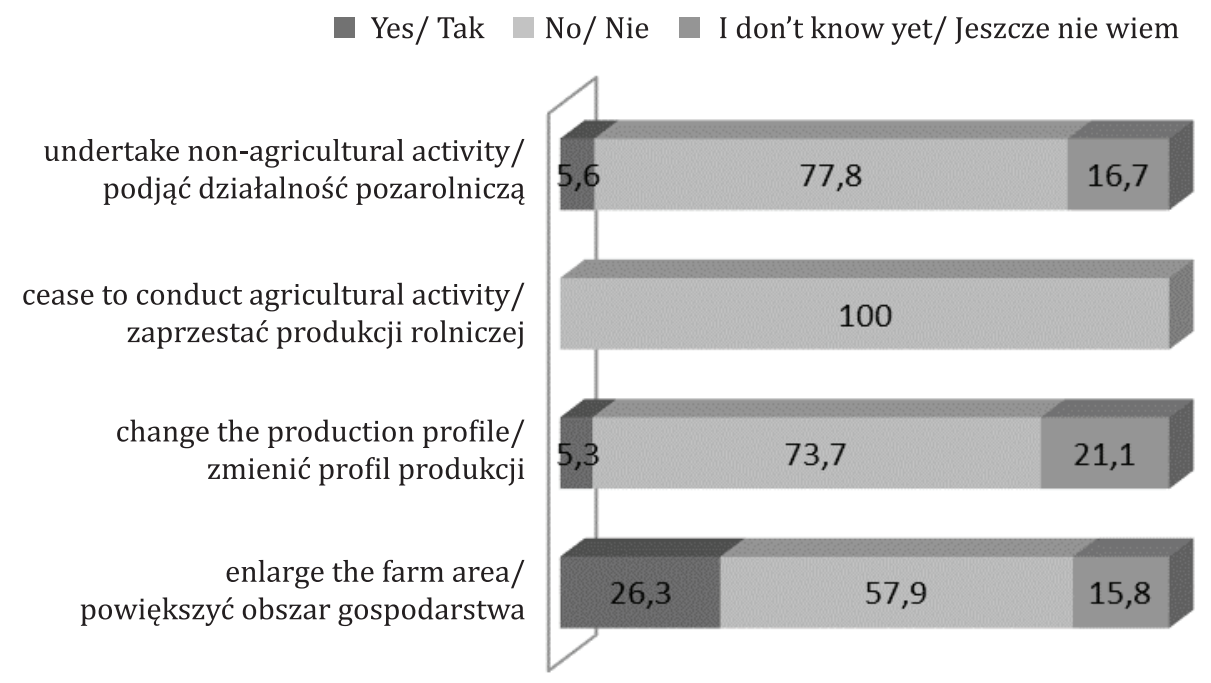

Figure 1. Plans associated with the conducted farming business for the next 5 years (in \%)

Wykres 1. Plany związane z prowadzonym gospodarstwem rolnym na najbliższe 5 lat (w \%)

Source: own elaboration.

Źródło: Badania własne.

One of the factors determining decisions connected to the agricultural production development is the level of income satisfaction. Among the managers of the surveyed farms, a significant majority replied that the level of income was satisfactory $(90 \%)$. Only one respondent indicated that he was considering an increase in production. The satisfaction with the achieved income level may result, among others, from the increase of this level. As indicated by the research conducted by G. Nachtman in a group of farms conducting certified ecological production (farms selected from the Polish database FADN), there was a significant rise of the income level during the years 2008-2010. The author indicated that the rise was a result of increasing subsidies (Nachtman 2013).

Among the respondents who gave their opinion on unsatisfactory income, motivating to even the reduction or cessation of ecological production, are producers whose income level from this type of production is less than $50 \%$ of the total income of the farm. It should be noted that in the surveyed group of farms there were also those for which the income from ecological production accounted for only a small percentage of the income from the farm. In 4 out of 20 entities the income from ecological production accounted for $10-25 \%$ of the total farm income. Only for five producers the income from ecological production amounted to $100 \%$ of the income from the farm.

By analysing the duration of certified ecological production, it was established that among the surveyed farms in Chełm-Zamość subregion the most numerous ones were the units that had conducted this production for 2 years ( 5 farms). 3 entities had an experience of over 10 years in this field. The entities pursuing plant production (17 farms) dominated among the farms. The remaining farms conducted mixed production.
Jednym z czynników warunkujących decyzje związane z rozwojem produkcji rolniczej jest poziom zadowolenia z osiąganych dochodów. Wśród kierowników gospodarstw objętych badaniem znacząca większość była zdania, że poziom dochodów jest zadowalający (90\%). Tylko jeden respondent wskazał, iż rozważa zwiększenie produkcji. Satysfakcja z osiąganego poziomu dochodów wynikać może między innymi ze wzrostu ich poziomu. Jak wskazują badania przeprowadzone przez G. Nachtman w grupie gospodarstw prowadzących certyfikowaną produkcję ekologiczną (gospodarstwa wyselekcjonowane $\mathrm{z}$ bazy danych polskiego FADN) w latach 2008-2010 nastąpił znaczący wzrost poziomu osiąganych dochodów. Autorka badań wskazała, iż nastąpił on w skutek zwiększających się dotacji (Nachtman 2013).

Wśród respondentów, którzy wyrazili opinię o niezadowalających dochodach, skłaniających nawet do ograniczenia lub zaprzestania produkcji ekologicznej znaleźli się producenci, których poziom dochodów z tego rodzaju produkcji kształtuje się poniżej $50 \%$ ogółu dochodów gospodarstwa rolnego. Należy zaznaczyć, iż w badanej grupie gospodarstw były także takie, dla których dochód z produkcji ekologicznej stanowił jedynie niewielki procent dochodów gospodarstwa rolnego. Z grupy 20 podmiotów, w przypadku 4 dochód z produkcji ekologicznej stanowił w granicach $10-25 \%$ całości dochodów gospodarstwa rolnego. Jedynie dla pięciu producentów dochody z produkcji ekologicznej wynosiły 100\% dochodów z gospodarstwa rolnego.

Analizując okres prowadzonej certyfikowanej produkcji ekologicznej stwierdzono, że wśród badanych gospodarstw z podregionu chełmsko-zamojskiego najliczniej wystąpiły jednostki realizujące ją przez okres 2 lat (5 gospodarstw). Doświadczenie w tym zakresie powyżej 10 lat posiadały 3 podmioty. Wśród gospodarstw dominowały podmioty z roślinna produkcją 
The implementation of agricultural plant production is associated with the possession of an equipment pool as well as infrastructure for fixed assets. One of the elements of both farm and household equipment is a car. It was the only element of equipment that was possessed by all of the surveyed farms. Other equally important machinery types are tractors and transport equipment along with delivery vans. Among the farms producing ecological food, the tractor was an element of the machinery pool in the case of $75 \%$ of the entities, while the other two items were owned by $60 \%$ of the farms.

Due to the dominance of farms focused on plant production in the surveyed group, the machinery pool required for this activity was also analysed (Figure 2).

The analysed ecological farms were best equipped with tractor mounted sprayers (65\%), tractor towed harvesters (55\%), manure spreaders (45\%) and lime and fertiliser spreaders (45\%).

The research was carried out on a group of 70 farms in Biłgoraj county by Z. Wasąga showed that the level of equipping farms with the means of mechanisation was characterized by an upward tendency. It was particularly visible during the period before and after subsidising from EU funds. Z. Wasąg also points to the problem of unreasonable usage of agricultural machinery (Wasąg 2011). Therefore, apart from the fact of owning machines and equipment alone, the important aspect is the level of their application in agricultural production. In the opinion of farm managers, a significant part of the machinery and equipment was used merely up to $25 \%$ of their capacity (e.g.: potato planters, manure spreaders). This indicates that the financial resources invested in the exploitation of the possessed machines are not fully utilised.

tractor mounted sprayers/ polowe opryskiwacze ciągnikowe tillage and sowing units/ agregaty uprawowe manure spreaders/ rozrzutnik obornika fertiliser and lime spreaders/ rozsiewacze nawozów i wapnia potato planters/ sadzarki do ziemniaków potato diggers/ kopaczki do ziemniaków loaders/ ładowacze pick-up balers/ prasy zbierające self-loading trailers/ przyczepy zbierające tractor towed harvesters/ kosiarki ciągnikowe forage harvesters/ silosokombajny sugar beet harvesters/ kombajny buraczane potato harvesters/ kombajny ziemniaczane crop harvesters/ kombajny zbożowe rolniczą (17 gospodarstw). Pozostałe gospodarstwa prowadziły produkcję mieszaną.

Realizacja roślinnej produkcji rolniczej związana jest posiadaniem parku maszynowego, a także infrastruktury w zakresie środków trwałych. Jednym z elementów wyposażenia zarówno gospodarstwa rolnego, jak również gospodarstwa domowego, jest samochód osobowy. Był on jedynym elementem wyposażenia, który stanowił przedmiot posiadania wszystkich badanych gospodarstw. Innymi równie ważnymi są ciągniki oraz urządzenia transportowe i samochody dostawcze. Wśród gospodarstw produkujących żywność ekologiczną ciaggnik stanowił element parku maszynowego w przypadku $75 \%$ podmiotów, zaś dwa pozostałe elementy były w posiadaniu $60 \%$ gospodarstw.

$\mathrm{Z}$ uwagi na to, iż w badanej grupie dominowały gospodarstwa ukierunkowane na produkcję roślinną, analizie poddano park maszynowy niezbędny do prowadzenia tej działalności (wykres 2).

Analizowane gospodarstwa ekologiczne były najlepiej wyposażone $\mathrm{w}$ polowe opryskiwacze ciągnikowe (65\%), kosiarki ciągnikowe (55\%), rozrzutniki obornika (45\%) oraz rozsiewacze nawozów i wapnia (45\%).

Badania zrealizowane na grupie 70 gospodarstw rolnych powiatu biłgorajskiego przez Z. Wasąga wskazały, iż poziom wyposażenia gospodarstw w środki mechanizacji charakteryzował się tendencją wzrostowa. Szczególnie uwidoczniło się to w okresie przed i po dofinansowaniu z funduszy UE. Z. Wasąg wskazuje również na problem nieracjonalnego wykorzystania maszyn i urządzeń rolniczych (Wasąg 2011). Dlatego też poza samym faktem posiadania maszyn i urządzeń ważnym aspektem jest stopień ich wykorzystania $\mathrm{w}$ realizowanej produkcji rolniczej. W opinii kierowników gospodarstw znaczna część maszyn i urządzeń była wykorzystywana zaledwie do $25 \%$ możliwości (np.: sadzarki do ziemniaków, rozrzutniki obornika).

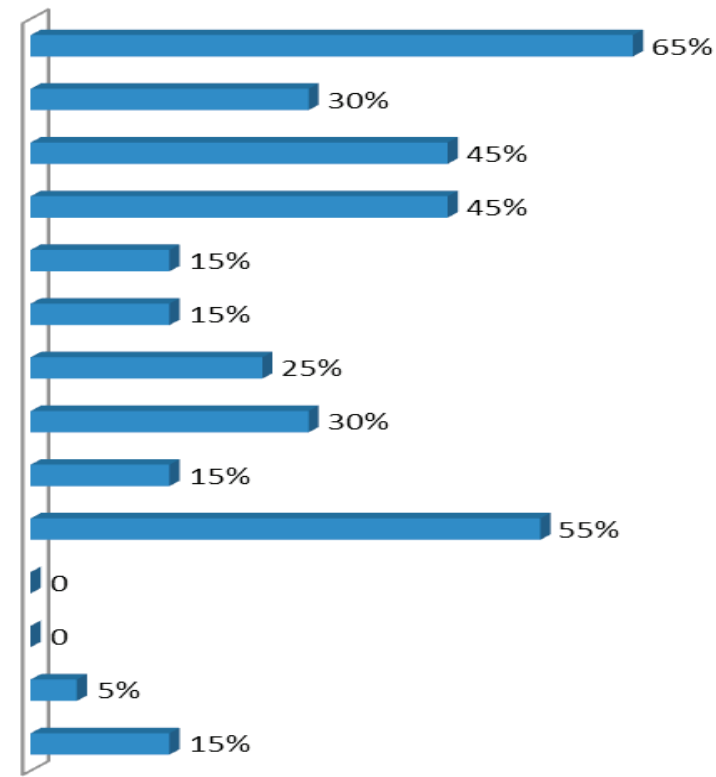

Figure 2. The level of machinery equipment used by ecological farms in plant production Wykres 2. Stopień wyposażenia gospodarstw ekologicznych w maszyny do produkcji roślinnej Source: own elaboration. Źródło: Badania własne. 
Running an agricultural activity is associated with exerting an influence on the environment. The farmer's knowledge in this area enables them to take action connected with caring for the environment and reducing the negative impact of the conducted production on natural resources. The surveyed respondents subjectively assessed the level of their knowledge on environmental issues. This assessment was made on a three-tier scale, where 1 indicated a low level of knowledge, 2 medium, and 3 high. The vast majority of the respondents indicated that their knowledge of environmental issues and environment protection was at a medium level (70\%). Only one person stated a high level of knowledge of environment protection issues. The other respondents rated their knowledge at a very low level.

The impact on the natural environment, both with regard to running a household and a farm, may include areas such as soil protection, climate change mitigation, water saving and maintenance of its quality, habitat and biodiversity conservation, landscape protection, waste management. In the three out of seven surveyed areas of environmental impact the respondents did not indicate any form of activity. Most actions were taken to protect the soil. In other cases, these were individual activities.

With regard to waste management, all respondents reported waste sorting. This is related to amendments in the Act on Maintaining Cleanliness and Order in Communes Nearly one third of the respondents indicated that before the amendment of legislation came into force no waste was segregated in their households.

Among the activities undertaken by the respondents to save resources only the collection of rainwater for reuse was stated.
Wskazuje to na niepełne wykorzystanie zainwestowanych środków finansowych w eksploatację posiadanych maszyn.

Prowadzenie działalności rolniczej wiąże się z oddziaływaniem na środowisko naturalne. Wiedza rolnika w tym zakresie pozwala na podejmowanie działań związanych z dbałością o środowisko naturalne i ograniczaniem negatywnego wpływu prowadzonej produkcji na zasoby naturalne. Badani respondenci dokonywali subiektywnej oceny poziomu swojej wiedzy z zakresu problematyki ochrony środowiska. Ocena ta dokonywana była w trzystopniowej skali, gdzie 1 oznaczało niski poziomi wiedzy, 2 średni, zaś 3 wysoki. Zdecydowana większość badanych producentów wskazała, iż stan ich wiedzy na tematy związane ze środowiskiem i jego ochroną jest na poziomie średnim (70\%). Jedynie jedna osoba wskazała na wysoki poziom znajomość problematyki ochrony środowiska. Pozostali respondenci ocenili swoją wiedzę na zdecydowanie niskim poziomie.

Oddziaływanie na środowisko naturalne zarówno $\mathrm{w}$ ramach prowadzonego gospodarstwa domowego, jak i rolnego, może obejmować takie obszary, jak: ochrona gleb, łagodzenie zmian klimatycznych, oszczędzanie oraz utrzymanie jakości wody, ochrona siedlisk i bioróżnorodności, ochrona krajobrazu, gospodarka odpadami. W trzech na siedem badanych obszarów oddziaływania na środowisko respondenci nie wskazali ani jednej formy aktywności. Najwięcej działań podejmowano w celu ochrony gleb. W pozostałych przypadkach były to pojedyncze aktywności.

W odniesieniu do gospodarki odpadami wszyscy badani wskazali na segregację odpadów. Jest to związane ze zmianami w Ustawie o utrzymaniu czystości i porządku w gminach. Blisko $1 / 3$ respondentów wskazało, iż przed wejściem zmian w ustawie w ich gospodarstwie domowym nie segregowano odpadów.

Table 2. Examples of activities undertaken on respondents' farms aimed at reducing the negative impact of agriculture on the environment in selected areas

Tabela 2. Przykłady działań podejmowanych w gospodarstwach respondentów, zmierzających do zmniejszania negatywnego oddziały wania rolnictwa na środowisko w wybranych obszarach

\begin{tabular}{|l|l|}
\hline \multicolumn{1}{|c|}{ Details/Wyszczególnienie } & \multicolumn{1}{c|}{ Examples of activities/Przykłady działań } \\
\hline $\begin{array}{l}\text { Soil protection/ } \\
\text { Ochrona gleb }\end{array}$ & $\begin{array}{l}\text { crop rotation, prevention of erosion, optimum use of fertilizers, rational } \\
\text { crop cultivation/ } \\
\text { płodozmian, zapobieganie erozji, optymalne stosowanie nawozów, racjonal- } \\
\text { ne uprawy }\end{array}$ \\
\hline $\begin{array}{l}\text { Climate change mitigation/ } \\
\text { Lagodzenie zmian klimatu }\end{array}$ & $\begin{array}{l}\text { no indications/ } \\
\text { brak wskazań }\end{array}$ \\
\hline $\begin{array}{l}\text { Savings in water consumption/ } \\
\text { Oszczędzane zużycie wody }\end{array}$ & $\begin{array}{l}\text { efficient water management/ } \\
\text { oszczędne gospodarowanie wodą }\end{array}$ \\
\hline $\begin{array}{l}\text { Water saving and maintenance of its quality/ } \\
\text { Utrzymanie i poprawa jakości wody }\end{array}$ & $\begin{array}{l}\text { no indications/ } \\
\text { brak wskazań }\end{array}$ \\
\hline $\begin{array}{l}\text { Conservation of habitats and biodiversity/ } \\
\text { Ochrona siedlisk i bioróżnorodności }\end{array}$ & $\begin{array}{l}\text { leaving midfield clusters of bushes/ } \\
\text { pozostawianie kęp krzaków śródpolnych }\end{array}$ \\
\hline $\begin{array}{l}\text { Landscape protection/ } \\
\text { Ochrona krajobrazu }\end{array}$ & $\begin{array}{l}\text { no indications / } \\
\text { brak wskazań }\end{array}$ \\
\hline $\begin{array}{l}\text { Waste management/ } \\
\text { Gospodarka odpadami }\end{array}$ & $\begin{array}{l}\text { waste sorting/ } \\
\text { segregacja odpadów }\end{array}$ \\
\hline
\end{tabular}

Source: own elaboration.

Źródło: Badania własne. 
With regard to the actions undertaken by the respondents and intended to reduce the impact on the environment, minimal attention to environmental protection issues can be observed. However, one can also point out the lack of ability to link farm activity with preventing degradation of the natural environment. Among other things, in the case of soil protection, ecological production does not use chemical plant protection products, which by itself positively influences the soil or improves water quality and protects biodiversity. Ecological production is the type of agricultural production which, in addition to the demand fulfilment function associated with the provision of environmental goods to the market, fulfils a social function associated with actions undertaken for the common good. This type of action is associated with contributions to environmental protection, animal welfare and rural development (Grabowski et al. 2014).

Farms pursuing ecological production are characterized by a higher level of ecological awareness, which results, among other things, from the specific nature of their activity and the knowledge gained by farm managers from certificating institutions. However, the results showed no connection between the specific nature of the undertaken activity and its impact on the natural environment.

A significant issue in the field of caring for the natural environment is to understand the impact of individual activities on their resources and valuable assets. The subjective perceptions of the respondents in the assessment of their farm's influence on the state of the natural environment of a given commune with its resources and values indicate that in the opinion of over $50 \%$ of respondents it is average. Nearly $40 \%$ of respondents reported no influence. Only 5\% rated this impact as considerable.

The obtained results indicate that farmers have little awareness of the impact of conducted production on the nearest environment. The respondents who indicated any environmental impact of their farm on the environment considered it to be positive $(64 \%)$.

Analysing the positive effects on the natural environment, the respondents indicated mainly actions related to the protection of endangered species and natural habitats, adoption of sustainable practices in the field of fisheries and forestry - Table 3.

Analysing the respondents' responses, it can be assumed that in their opinion few activities associated with the conducted agricultural production adversely affect the natural environment. Among the sixteen symptoms of negative impact, rated on a scale from 1 to 5 , the average rating ranged from 1.18 to 1.50 . The farmers stated that agricultural production has little or no impact on the emissions of odours, sewage or the consumption of raw natural resources.

The respondents pointed out that their activity had little impact on the consumption of raw natural resources, the landscape and the aesthetics of the environment. Such an opinion can be justified by the specific nature of ecological production, which
Wśród działań podejmowanych przez respondentów w celu oszczędnego gospodarowanie zasobami wymieniano jedynie zbieranie deszczówki do ponownego wykorzystania.

Odnosząc to do podejmowanych działań, zadeklarowanych przez respondentów, zmierzających do zmniejszenia oddziaływania na środowisko naturalne można zaobserwować minimalne zainteresowanie kwestiami ochrony środowiska naturalnego. Jednakże można również wskazać brak umiejętności powiązania aktywności w gospodarstwie a przeciwdziałaniem degradacji środowiska przyrodniczego. Między innymi w przypadku ochrony gleb produkcja ekologiczna nie wykorzystuje chemicznych środków ochrony roślin, przez sam ten fakt pozytywnie wpływa na glebę czy też na poprawę jakości wód, ochronę bioróżnorodności. Produkcja ekologiczna jest tym rodzajem produkcji rolniczej, który poza funkcja popytową związaną z dostarczaniem dóbr ekologicznych na rynek pełni funkcje społeczną związaną z działaniem w interesie publicznym. Działanie to związane jest z przyczynianiem się do ochrony środowiska, dobrostanu zwierzat oraz rozwoju obszarów wiejskich (Grabowski i in. 2014).

Gospodarstwa prowadzące produkcję ekologiczną charakteryzują się wyższym poziomem świadomości ekologicznej, co wynika między innymi ze specyfiki prowadzonej działalności, a także z wiedzy którą kierownicy gospodarstw pozyskują z instytucji certyfikujących. Jednakże uzyskane wyniki wskazały na brak powiązania specyfiki podejmowanej działalności a jej wpływem na środowisko przyrodnicze.

Znaczącą kwestią w dbałości o środowisko przyrodnicze jest zrozumienie wpływu działalności prowadzonej przez poszczególne osoby na jego zasoby i walory. Subiektywne odczucia respondentów w zakresie oceny siły wpływu prowadzonego gospodarstwa rolnego na stan środowiska przyrodniczego gminy, jego zasoby oraz walory wskazują, iż w opinii ponad $50 \%$ badanych jest ona przeciętna. Blisko $40 \%$ respondentów wskazało na brak wpływu. Jedynie 5\% zaś oceniło ten wpływ jako duży.

Uzyskane wyniki wskazują, iż rolnicy mają niewielką świadomość oddziaływania realizowanej produkcji na najbliższe otoczenie. Badani, którzy wskazywali na jakiekolwiek oddziaływanie gospodarstwa na środowisko, w zdecydowanej większości uważali, że jest ono pozytywne (64\%).

Analizując przejawy pozytywnego wpływu na środowisko przyrodnicze respondenci wskazali głównie na działania związane $\mathrm{z}$ ochroną zagrożonych gatunków oraz siedlisk przyrodniczych, przyjmowaniem zrównoważonych praktyk w dziedzinie rybołówstwa i leśnictwa - tabela 3.

Analizując odpowiedzi respondentów można przypuszczać, iż w ich opinii niewiele działań związanych z prowadzoną produkcją rolniczą wpływa negatywnie na środowisko przyrodnicze. Wśród szesnastu przejawów negatywnego oddziaływania, ocenianych w skali od 1 do 5, średnia ocena wahała się w granicach 1,181,50. Rolnicy uważali, że prowadzona produkcja rolna w małym stopniu oddziałuje na emisję zapachów, ścieków czy też zużycie surowców naturalnych. 
Table 3. Types of farming activities that positively impact the natural environment

Tabela 3. Rodzaje działalności gospodarstw wpływające pozytywnie na środowisko przyrodnicze

\begin{tabular}{|c|c|c|c|c|c|}
\hline \multirow[b]{2}{*}{$\begin{array}{l}\text { Symptoms of positive impact/ } \\
\text { Przejawy pozytywnego wpływu }\end{array}$} & \multicolumn{5}{|c|}{$\begin{array}{l}\text { Farmers' responses }(\%) / \\
\text { Odpowiedzi rolników (\%) }\end{array}$} \\
\hline & $\begin{array}{l}\text { Definitely } \\
\text { yes/ } \\
\text { Zdecydo- } \\
\text { wanie tak }\end{array}$ & $\begin{array}{l}\text { Rather } \\
\text { yes/ } \\
\text { Raczej tak }\end{array}$ & \begin{tabular}{|l|} 
Difficult to \\
say/ \\
Trudno po- \\
wiedzieć
\end{tabular} & $\begin{array}{l}\text { Not really/ } \\
\text { Raczej nie }\end{array}$ & $\begin{array}{l}\text { Definitely } \\
\text { not/ } \\
\text { Zdecydo- } \\
\text { wanie nie }\end{array}$ \\
\hline $\begin{array}{l}\text { We identify potential negative impacts of the farm on } \\
\text { the biodiversity and functions of natural ecosystems and } \\
\text { undertake measures to minimise it./ } \\
\text { identyfikujemy potencjalny negatywny wpływ gospo- } \\
\text { darstwa na różnorodność biologiczną i funkcje natural- } \\
\text { nych ekosystemów oraz podejmujemy działania aby go } \\
\text { zminimalizować }\end{array}$ & 6.3 & 31.1 & 50.0 & 6.3 & 6.3 \\
\hline $\begin{array}{l}\text { We undertake measures to protect endangered species } \\
\text { or natural habitats that may be adversely affected by the } \\
\text { impact of the farm/ } \\
\text { podejmujemy działania w celu ochrony zagrożonych ga- } \\
\text { tunków lub siedlisk przyrodniczych, które mogą podle- } \\
\text { gać niekorzystnemu oddziaływaniu gospodarstwa }\end{array}$ & 18.8 & 56.2 & 25.0 & 0 & 0 \\
\hline $\begin{array}{l}\text { we adopt sustainable practices in the fields of agricultu- } \\
\text { re/fishing and forestry/ } \\
\text { przyjmujemy zrównoważone praktyki w dziedzinie rol- } \\
\text { nictwa/rybołówstwa i leśnictwa }\end{array}$ & 13.3 & 66.7 & 20.0 & 0 & 0 \\
\hline $\begin{array}{l}\text { we care for animal welfare/ } \\
\text { dbamy o dobrostan zwierząt }\end{array}$ & 33.3 & 11.1 & 44.5 & 0 & 11.1 \\
\hline $\begin{array}{l}\text { We avoid methods and attitudes that threaten the survi- } \\
\text { val or lead to extinction of species or allow for the spread } \\
\text { of invasive species/ } \\
\text { unikamy metod i postaw zagrażających przetrwaniu lub } \\
\text { prowadzących do wymierania gatunków lub umożliwia- } \\
\text { jących rozprzestrzenianie się gatunków inwazyjnych }\end{array}$ & 37.4 & 31.3 & 31.3 & 0 & 0 \\
\hline $\begin{array}{l}\text { we exert a positive influence on the environment } \\
\text { aesthetics/ } \\
\text { wywieramy pozytywny wpływ na estetyke otoczenia }\end{array}$ & 37.5 & 43.8 & 18.8 & 0 & 0 \\
\hline
\end{tabular}

Source: own elaboration.

Źródło: Badania własne.

is one of the systems of agricultural production that impacts the natural environment in a balanced manner. Ecological farming is characterized by, among others, the use of ecological fertilisation, crop rotation, catch crops, minimising the use of non-renewable resources (Żelezik 2009).

Conducting all kinds of agricultural production results in substantial energy consumption, generation of waste or energy consumption. The obtained results may indicate that the respondents are not fully aware of the impact on the natural environment. Farm managers pointed to a definitely small average usage of individual resource types.

Both the implementation of agricultural production as well as household management is associated with the possibility of introducing new pro-ecological technologies on the farm. Only seven of the surveyed respondents were interested in such solutions like: industrial technologies, solar collectors, self-cleaning septic tanks. Some of the respondents were unable to state the type of investment.

Therefore, the question arises about the reasons for not considering and, consequently, not implementing pro-ecological solutions on farms. One of
Badani respondenci wskazali, iż prowadzona przez nich działalność w małym stopniu wpływa na zużycie surowców naturalnych, krajobraz oraz estetykę otoczenia. Opinie taką można uzasadnić specyfiką produkcji ekologicznej, która stanowi jeden z systemów produkcji rolniczej oddziałujący na środowisko przyrodnicze w sposób zrównoważony. Rolnictwo ekologiczne charakteryzuje się między innymi wykorzystywaniem nawożenia organicznego, płodozmianu, poplonów, ograniczaniem do minimum stosowania zasobów nieodnawialnych (Żelezik 2009).

Prowadzenie wszelkiego rodzaju produkcji rolniczej wiąże się ze zużyciem wód, powstawaniem odpadów, czy też zużyciem energii. Uzyskane wyniki mogą wskazywać na nie pełną świadomość respondentów w zakresie oddziaływania na środowisko przyrodnicze. Kierownicy gospodarstw wskazali na zdecydowanie niewielkie średnie wykorzystywanie poszczególnych zasobów.

Zarówno realizacja produkcji rolniczej, jak również prowadzenie gospodarstwa domowego wiąże się $\mathrm{z}$ możliwościa wprowadzania $\mathrm{w}$ gospodarstwie nowych proekologicznych technologii. Wśród badanych producentów jedynie siedmiu było zainteresowanych 
Table 4. Assessing the impact of farming activity on the natural environment by the surveyed ecological farmers * Tabela 4. Ocena wpływu działalności gospodarstwa rolnego na środowisko przyrodnicze przez badanych rolników ekologicznych*

\begin{tabular}{|c|c|c|}
\hline $\begin{array}{l}\text { Symptoms of negative impact/ } \\
\text { Przejawy negatywnego wpływu }\end{array}$ & $\begin{array}{l}\text { Averag/ } \\
\text { Średnia }\end{array}$ & $\begin{array}{c}\text { Standard deviation/ } \\
\text { Odchylenie standardowe }\end{array}$ \\
\hline consumption of raw natural resources/ zużycie surowców naturalnych & 1.37 & 0.88 \\
\hline interference in the landscape/ ingerencja w krajobraz & 1.25 & 0.77 \\
\hline aesthetics of the environment/ estetyka otoczenia & 1.5 & 1.09 \\
\hline negative impact on natural habitats/ negatywny wpływ na siedliska naturalne & 1.25 & 0.58 \\
\hline $\begin{array}{l}\text { possibility of biological hazard emergence (e.g. invasive species)/ } \\
\text { możliwość powstania zagrożeń biologicznych (np. gatunki inwazyjne) }\end{array}$ & 1.25 & 0.58 \\
\hline emissions of odours/ emisja zapachów & 1.25 & 0.57 \\
\hline sewage release/ emisja ścieków & 1.43 & 0.57 \\
\hline greenhouse gases/dust emissions/ emisja gazów/pyłów & 1.43 & 0.89 \\
\hline substantial water consumption/ znaczne zużycie wody & 1.18 & 0.54 \\
\hline noise and vibration emissions/ emisja hałasu i wibracji & 1.18 & 0.40 \\
\hline $\begin{array}{l}\text { generation of waste requiring processing/ powstawanie odpadów wymagają- } \\
\text { cych utylizacji }\end{array}$ & 1.31 & 0.79 \\
\hline substantial energy consumption/ znaczne zużycie energii & 1.43 & 0.89 \\
\hline $\begin{array}{l}\text { application and disposal of toxic and hazardous substances in industry/ } \\
\text { stosowanie i unieszkodliwianie substancji toksycznych i niebezpiecznych } \\
\text { w przemyśle }\end{array}$ & 1.18 & 0.54 \\
\hline $\begin{array}{l}\text { application of materials in agricultural production/ } \\
\text { stosowanie materiałów w produkcji rolnej }\end{array}$ & 1.37 & 0.80 \\
\hline electromagnetic emissions/ emisje elektromagnetyczne & 1.50 & 1.21 \\
\hline emissions of ionising radiation/ emisja promieniowania jonizującego & 1.25 & 0.77 \\
\hline
\end{tabular}

${ }^{*}$ Assessment on a scale from 1 to 5, where: 5 - Definitely yes, 4 - rather yes, 3 - difficult to say 2 - not really, 1 - definitely not *Ocena w skali od 1 do 5, gdzie: 5-zdecydowanie tak, 4-raczej tak, 3-trudno powiedzieć, 2-raczej nie, 1-zdecydowanie nie

Source: own elaboration.

Źródło: Badania własne.

the causes may be the lack of financial resources that could be committed to investments. In addition, the respondents did not report the need for such investments, which is far more worrying due to the development of innovative solutions in rural areas, especially among ecological producers

\section{Conclusions}

This study established a lack of awareness or very low awareness of the surveyed ecological farmers in relation to the use of resources and environmental assets in the agricultural production carried out on their farms.

Among the measures aimed at achieving sustainable management of environmental resources the surveyed ecological farmers reported only economical water management. The respondents are not aware of such measures in the case of remaining resources. They do not link the specific nature of their activity with caring for the natural environment.

There are no additional activities beyond the tego rodzaju rozwiązaniami, takimi jak: technologie przemysłowe, kolektory słoneczne, szamba samooczyszczające. Część z badanych nie potrafiła podać rodzaju inwestycji.

Pojawia sięzatem pytanie o powody nie rozważania i w konsekwencji nie wprowadzania rozwiązań proekologicznych w gospodarstwach. Jedną z przyczyn może być brak środków finansowych, które mogłyby być przeznaczone na inwestycje. Ponadto respondenci nie wykazywali potrzeby takich inwestycji, co jest znacznie bardziej niepokojące ze względu na rozwój innowacyjnych rozwiązań na obszarach wiejskich, zwłaszcza wśród producentów żywności ekologicznej

\section{Wnioski}

Stwierdzono brak świadomości lub bardzo niewielką świadomość badanych rolników ekologicznych w kwestii wykorzystywania zasobów i walorów środowiskowych przez produkcję rolniczą prowadzoną $\mathrm{w}$ gospodarstwie.

Wśród działań zmierzających do zrównoważonego gospodarowania zasobami środowiska badani rolnicy ekologiczni wymieniali jedynie oszczędne gospodarowanie wodą. W przypadku pozostałych zasobów respondenci nie mają świadomości realizowania takich działań. Nie wiążą specyfiki prowadzonej przez siebie działalności z dbałością o środowisko przyrodnicze.

Brak dodatkowych działań, wykraczających poza 
requirements of ecological production or activities implemented by a small number of surveyed farms in connection with minimising environmental impacts. It can be assumed that there is a lack of awareness that the respondents' actions are aimed at taking care of the environment and its resources (refraining from field burning on arable lands by more than $90 \%$ of respondents, applying minimum norms of arable land maintenance).

Lack of interest in the implementation of additional investments intended to protect the environment. The main factor preventing the respondents from undertaking measures associated with implementing pro-ecological investments is mainly the lack of financial resources and failure to perceive the need for such measures.

It seems desirable to build a tool for the objective assessment of the level of ecological awareness and knowledge on environmental issues so that one could strive to apply it in the management of households. Which refers not only to agricultural activities but also to consumer ones. wymagania produkcji ekologicznej, lub realizowane w nieznacznej liczbie badanych gospodarstw związanych ze zmniejszeniem oddziaływania na środowisko. Można również przypuszczać, iż brak jest świadomości, że działania podejmowane przez respondentów mają na celu dbanie o środowisko i jego zasoby (nie wypalanie gruntów ornych przez ponad 90\% badanych, stosowanie minimalnych norm utrzymania gruntów ornych).

Brak zainteresowania realizacja dodatkowych inwestycji mających na celu ochronę środowiska. Czynnikiem powstrzymującym badanych przed podejmowaniem działań związanych z realizacją inwestycji proekologicznych, mających na celu ochronę środowiska, jest głównie brak środków finansowych oraz nie dostrzeganie potrzeb tego rodzaju.

Wydaje się, iż wskazane jest dążenie do zbudowania narzędzia pozwalającego na obiektywną ocenę poziomu świadomości ekologicznej i stanu wiedzy w zakresie kwestii środowiskowych tak aby można było dążyć do jej wykorzystywania w prowadzonej działalności gospodarstw domowych. Nie tylko działalności rolniczej ale również konsumpcyjnej.

\section{References/Literatura:}

1. Grabowski M., Barszczewski J., Grzelak M. (2014), Specyfika sposobów gospodarowania w ekologicznym systemie produkcji w regionie pomorskim. Woda-Środowisko-Obszary Wiejskie, t. 14, z. 4(48), s. 27-43.

2. Nachtman G. (2013), Dochodowość gospodarstw ekologicznych a wielkość użytków rolnych. Roczniki Ekonomii Rolnictwa i Rozwoju Obszarów Wiejskich, t. 100, z. 1, s. 182-196.

3. Quinn M.G. (2010), Bioeconomy for a better life. Conference The Knowledge-Based Bio-Economy Towards 2020, Brussels, $14^{\text {th }}$ September 2010.

4. Siedlecka A. (2013), Uwarunkowania ekologizacji rolnictwa w województwie lubelskim w opinii respondentów. Roczniki Naukowe Stowarzyszenia Ekonomistów Rolnictwa i Agrobiznesu, t. XV, z. 3, s. 301-305.

5. Wasąg Z. (2011), Wyposażenie techniczne wybranych gospodarstw rolnych korzystających z funduszy Unii Europejskiej. Inżynieria Rolnicza, nr 1(126), s. 265-271.

6. Żelezik M. (2009), Dlaczego rolnictwo ekologiczne? Rocznik Świętokrzyski. Ser. B - Nauki Przyr. 30, s. 155-166.

7. Ustawa Prawo ochrony środowiska, Dz.U. z 2008 nr 25 poz. 150, art. 3, Tekst obowiązujący od 28 maja 2012.

\section{Websites/ Strony internetowe:}

8. Diagnoza sytuacji społeczno-gospodarczej województwa lubelskiego, Urząd Marszałkowski Województwa Lubelskiego w Lublinie, Departament Polityki Regionalnej, Lublin 2012, strategia. $<$ b $>$ lubelskie $</$ b $>$.pl $/<b>$ Diagnoza $</ b>\% 2005.09$.docx, (data dostępu: 10.06.2014).

9. Gołębiewski J. (2013), Zrównoważona biogospodarka - potencjał i czynniki rozwoju, http://www.pte.pl/kongres/referaty/ Gołębiowski\%20Jarosław/Gołębiewski\%20Jarosław\%20-\%20ZRÓWNOWAŻONA\%20BIOGOSPODARKA\%20-\%20POTENCJAŁ\%20I\%20CZYNNIKI\%20ROZWOJU.pdf, (data dostępu: 10.06.2014).

10. Komunikat Komisji do Parlamentu Europejskiego, Rady, Europejskiego Komitetu Ekonomiczno-Społecznego i Komitetu Regionów, Strategia „Innowacje w służbie zrównoważonego wzrostu: biogospodarka dla Europy”, Bruksela, dnia 13.2 .2012 r., COM(2012), http://ec.europa.eu/research/bioeconomy/pdf/201202_innovating_sustainable_growth_pl.pdf, (data dostępu: 10.06.2014)

11. Polska Agencja Informacji i Inwestycji Zagranicznych, 2013, http://www.paiz.gov.pl/files/?id_plik=21744, (data dostępu: 06.06.2014).

12. Ratajczak E. (2013), Rolnictwo i leśnictwo w świetle koncepcji biogospodarki, http://www.pte.pl/kongres/referaty/Ratajczak\%20Ewa/Ratajczak\%20Ewa\%20-\%20ROLNICTWO\%20I\%20LE\%C5\%9ANICTWO\%20W\%20\%C5\%9AWIETLE\%20 KONCEPCJI\%20BIOGOSPODARKI.pdf, (data dostępu: 06.06.2014).

13. Report of the World Commission on Environment and Development Our Common Future, United Nations, 1987; http://conspect. $\mathrm{nl} /$ pdf/Our_Common_Future-Brundtland_Report_1987.pdf, (data dostępu: 12.06.2014).

14. Sektor spożywczy w Polsce. Profil sektorowy, Departament Informacji Gospodarczej, www.paiz.gov.pl/files/?id_plik=21744, (data dostępu: 12.06.2014). 